Synthesis, part of a Special Feature on Do we need new management paradigms to achieve sustainability in tropical forests?

\title{
Landscape-scale Approaches for Integrated Natural Resource Management in Tropical Forest Landscapes
}

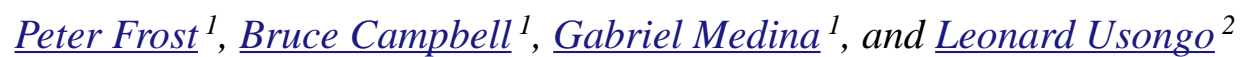

\begin{abstract}
Integrated natural resource management (INRM) helps resource users, managers, and others to manage resources sustainably by considering, reconciling, and synergizing their various interests and activities. Although many social and environmental problems have to be tackled at a range of scales to be resolved successfully, INRM has particular relevance at the landscape level at which the interests of local people first intersect those of the outside world. We propose eight guidelines for building successful INRM programs: focus on multiscale analysis and intervention; develop partnerships and engage in action research; facilitate change rather than dictating it; promote visioning and the development of scenarios; recognize the importance of local knowledge; foster social learning and adaptive management; concentrate on both people and their natural resources, including biodiversity; and embrace complexity. Reviewing these guidelines in the light of experiences from three separate studies shows that most are being done, though more as a product of happenstance than design. The guidelines form a mutually reinforcing framework for building INRM, primarily through empowering local stakeholders to be more articulate advocates and active participants in their own development and conservation efforts.
\end{abstract}

Key Words: action research; Brazil; Cameroon; collaboration; extractive reserves; integrated natural resource management; Kalimantan; multiscale analysis; multiple stakeholders; tropical forest landscapes

\section{INTRODUCTION}

Rural development in the tropics is typically sectoral. Many agriculture and forestry developments, for example, focus on identifying and promoting particular technologies, plant varieties, or land management options. The alleviated constraints are mainly those internal to household production systems. Instances of systemic changeovercoming extrasectoral and larger-scale constraints such as insecure tenure, unstable macroeconomic conditions, lack of incentives to make long-term investments, and inequities in access to land, capital, and markets - are rare. Progress is usually slow and dependent on incremental adoption of technologies and practices. Gains are sometimes offset by unforeseen adverse consequences, including progressive declines in soil structure and fertility, lower water quality, reduced biodiversity, and benefits that accrue mostly to wealthier farmers, agroindustries, or urban consumers, rather than to the intended beneficiaries (Harwood and Kassam
2003, Sayer and Campbell 2004).

Multisectoral approaches are less common despite the reality that people live integrated, not modular, lives. To turn the corner on poverty and underdevelopment requires broadening our perceptions of people's livelihoods, understanding their contexts, and looking for opportunities to trigger systemic change. On-farm developments need to be complemented by efforts to reduce larger-scale external constraints. Management plans, normally grounded in foreign technical and legal precepts, must encompass people's natural resource endowments, capital assets, and local knowledge and practices. Given the diversity and complexity of the systems involved, selecting the appropriate mix is challenging.

This paper proposes a more integrated approach to managing and conserving natural resources. Although sustainable development requires complementary changes at different levels of social 
and economic organization, landscapes are the first point of external constraint on household economic functioning and the scale at which many projects are implemented. We suggest eight guidelines for applying integrated natural resource management (INRM) at this scale. To give these a context and illustrate the need, we relate them to three ongoing initiatives in tropical forest resource management in which the Center for International Forestry Research (CIFOR) is involved. Each differs substantially from the others in its geographic, biophysical, and socioeconomic settings.

Following this introduction, we briefly explore the concept of INRM in Section 2, and then elaborate on the significance of taking a landscape-level approach in Section 3. In Section 4, we introduce the three background cases before setting out the eight guidelines for implementing INRM at the landscape level in Section 5. We conclude with some general observations on implementing INRM in tropical forested landscapes in Section 6.

\section{INTEGRATED NATURAL RESOURCE MANAGEMENT}

Integrated natural resource management (INRM) is an approach to managing resources sustainably by helping resource users, managers, and other stakeholders accomplish their different goals by consciously taking into account, and aiming to reconcile and synergize, their various interests, attitudes, and actions (Harwood and Kassam 2003, Sayer and Campbell 2004). These goals include increasing production, enhancing food security, creating value, maximizing profitability, minimizing risk, building up and maintaining various natural and other assets, and conserving the natural resource base. As such, INRM is interdisciplinary and multiscaled, encompassing different but linked levels of social and biophysical organization. It is responsive to different histories, sites, and circumstances, and is intended to integrate varied and complex sets of knowledge into a common framework for analysis and action (Sayer and Campbell 2004).

\section{INTEGRATED NATURAL RESOURCE MANAGEMENT AT THE LANDSCAPE LEVEL}

A landscape consists not only of interacting biological and geophysical elements but also of people, land uses, infrastructure, social organizations, institutional arrangements, and cultural, spiritual, and utility values. Most people link to wider-ranging markets and transport and communication networks at this level. Landscapes are also the primary level at which the actions of individual households intersect those of others resource users. The right to access, use and manage natural resources becomes subject to social convention and negotiation, themselves framed by more formal rules set down by distant government agencies. Together, these features shape people's lives and produce the natural resources, ecological services, and social and economic relationships on which they depend.

These relationships are pressured unpredictably by both local and distant economic change, advances in infrastructure and technology, widening access to markets and information, the growth and movement of populations, and variations in climate and other exogenous forces. People can seldom reduce or eliminate this complexity and uncertainty, at least in the short term. They cope by acting on best available knowledge, learning from the outcomes, and adapting accordingly. Understanding this complexity requires research driven less by the researchers and more by the perceptions, priorities, and actions of the land users. The results are usually more relevant and revealing. Such "action research," which is central to the concept of INRM, requires researchers and others to collaborate in sharing information, knowledge, and resources, and in undertaking joint activities, including research.

\section{THE NEED FOR INTEGRATED NATURAL RESOURCE MANAGEMENT: THREE BACKGROUND CASES}

The three background cases are drawn from Malinau District, East Kalimantan, Indonesia; TriNational de la Sangha, Cameroon; and Reserva Extrativista Verde para Sempre, Porto de Moz, Pará State, Brazil. The resource management context in each differs substantially (Table 1), as do the roles of researchers. In Indonesia, activities were initiated and directed by researchers, whereas in Cameroon the project was led by an international conservation organization, the World Wide Fund for Nature (WWF), with minimal input from researchers. In Brazil, the push for an integrated approach to natural resource management came largely from organizations representing land users, again 
initially with little input from researchers.

\section{Indonesia: sustainable development—securing forests and improving livelihoods}

The Center for International Forestry Research (CIFOR) began research in Malinau in the mid-1990s. The main problems then identified were those related to industrial logging by large state companies (Table 1). When Indonesia decentralized its government in 2000, small-scale logging expanded, especially in Malinau, which is close to timber markets in Malaysia. Extraordinarily high levels of timber extraction and conflict resulted. Local people saw few benefits. At the district level, the lack of finance and capacity constrained the ability of local government to manage the changing pressures on the district's natural resources brought about by new roads, increased logging and mining, planned oil palm plantations, high in-migration rates, many new economic opportunities, and shifts in the center of power (Campbell et al. 2003).

Timber is the most valuable resource, but much of its value is captured by merchants and district officials. Local people usually receive only about $5 \%$ of the timber's export value, and even this is often inequitably distributed (Engel and Palmer 2006; C. Palmer, personal communication). The distribution of benefits from other high-value natural products such as edible bird nests and eaglewood is often also inequitable, with small local elites gaining most.

A key objective of the current research program is to improve district coordination of forest management in the district. This involves building capacity to broaden and improve stakeholder participation, manage conflicts, develop and implement land-use plans, and monitor impacts. Other objectives are to enhance local livelihoods, increase local people's access to and control over forest benefits by encouraging participation in district-level decision making, and ensure that the rents from extractive industries accrue to the district administration and not to private individuals.

\section{Cameroon: large-scale conservation-what role for local livelihood improvement?}

Under colonialism in Africa, natural resources were effectively nationalized. Much land was set aside for conservation, displacing and marginalizing local people and alienating them from traditional resource areas (Colchester 1994, Davenport and Usongo 1997). This trend continued after independence. People have come to equate conservation with exclusion from protected areas, often weakening broader conservation initiatives aimed at sustainable use of natural resources. Wildlife is considered a nuisance, especially by farmers adjacent to reserves. With continued high human population growth, the pressures on protected areas are increasing. The challenge is how to move from outright protection to a system that takes account of the interests of local people while still conserving biodiversity.

The forests of the Congo Basin are important sources of timber, nontimber forest products including bush meat, and biodiversity. They also provide various environmental services and have many other values (Wilkie et al. 2001). Nevertheless, forest is being transformed to agricultural land, especially where local returns from protection and other land uses are low. Under current circumstances, this conversion is a better option for local people. For conservation to succeed, therefore, people's livelihoods must be improved and people must get tangible benefits from keeping at least some of the forest in its natural state.

Until recently, few wildlife and forest management agencies saw people as integral to so-called natural ecosystems; neither did some international conservation organizations. This is being turned around. In 1994, Cameroon enacted forestry and wildlife laws that provide for community involvement in natural resource management. Community forestry, public participation in planning and management, and benefit sharing are being promoted to ensure that income from the extraction of forest resources, notably timber, finances development in the production areas. In 2002, the Cameroon National Forest and Environment Sector Programme identified priority conservation areas and forms of forest-land use that could contribute to social development and improved livelihoods.

The initiative considered here stems from these 
Table 1. Characteristics of three forested regions in which the management of natural resources is being approached in an integrated way, and which illustrate the need for a coordinated and systematic approach exemplified by the integrated natural resource management guidelines.

\begin{tabular}{|c|c|c|c|}
\hline Feature & Malinau & Tri-National de la Sangha & $\begin{array}{l}\text { Reserva Extrativista } \\
\text { Verde para Sempre }\end{array}$ \\
\hline Location & $\begin{array}{l}2^{\circ} 45^{\prime}-3^{\circ} 21^{\prime} \mathrm{N} \\
115^{\circ} 48^{\prime}-116^{\circ} 34^{\prime} \mathrm{E}\end{array}$ & $\begin{array}{l}0^{\circ} 40^{\prime}-3^{\circ} 32^{\prime} \mathrm{N} \\
15^{\circ} 29^{\prime}-17^{\circ} 34^{\prime} \mathrm{W}\end{array}$ & $\begin{array}{l}1^{\circ} 35^{\prime}-2^{\circ} 49^{\prime} \mathrm{S} \\
52^{\circ} 03^{\prime}-53^{\circ} 32^{\prime} \mathrm{W}\end{array}$ \\
\hline Area & $2500 \mathrm{~km}^{2}$ & $36,236 \mathrm{~km}^{2}$ & $12,887 \mathrm{~km}^{2}$ \\
\hline Vegetation & $\begin{array}{l}\text { Lowland evergreen broadleaf } \\
\text { rain forest, upper montane forest, } \\
\text { secondary forest }\end{array}$ & $\begin{array}{l}\text { Primary and secondary mixed } \\
\text { species terra firma tropical semi- } \\
\text { evergreen rain forest, } \\
\text { monodominant (Gibertiodendron) } \\
\text { closed canopy forest, riparian } \\
\text { and swamp forest }\end{array}$ & $\begin{array}{l}\text { Seasonally flooded forest } \\
\text { (várzea), closed mixed forest }\end{array}$ \\
\hline Physical features & $\begin{array}{l}50-2000 \text { m elevation } \\
\text { Rugged topography }\end{array}$ & $\begin{array}{l}300-600 \text { m elevation } \\
\text { Flat topography } \\
\text { Poor soils }\end{array}$ & $\begin{array}{l}15-100 \text { m elevation } \\
\text { Flat topography intersected by } \\
\text { numerous rivers }\end{array}$ \\
\hline Population & $\begin{array}{l}40,000 \text { (estimate for Malinau } \\
\text { District) }\end{array}$ & Estimated 0.7 person $/ \mathrm{km}^{2}$ & 13,300 people in rural settlements \\
\hline Settlement & $\begin{array}{l}\text { Scattered settlements } \\
\text { One medium-sized town }\end{array}$ & $\begin{array}{l}\text { Scattered small villages of } 50- \\
100 \text { inhabitants, but people } \\
\text { increasingly concentrated around } \\
\text { logging towns, i.e., } 4500-15,000 \\
\text { inhabitants }\end{array}$ & $\begin{array}{l}\text { Small settlements along rivers } \\
\text { One medium-sized town }\end{array}$ \\
\hline Land use & $\begin{array}{l}\text { Large- to medium-scale } \\
\text { industrial logging } \\
\text { Coal mining } \\
\text { Swidden agriculture } \\
\text { Agroforestry } \\
\text { Nontimber forest product } \\
\text { (NTFP) extraction, i.e., rattan, } \\
\text { eaglewood, bird nests, resin, and } \\
\text { fuelwood }\end{array}$ & $\begin{array}{l}\text { Largescale industrial logging } \\
\text { Artisanal alluvial diamond } \\
\text { mining } \\
\text { Sport hunting } \\
\text { Ecotourism } \\
\text { Swidden agriculture } \\
\text { Hunting, fishing, and gathering } \\
\text { NTFPs }\end{array}$ & $\begin{array}{l}\text { Largely illegal commercial } \\
\text { logging } \\
\text { Hunting and fishing } \\
\text { Swidden agriculture } \\
\text { Harvesting NTFPs, e.g., fruits, } \\
\text { nuts, medicinal plants }\end{array}$ \\
\hline $\begin{array}{l}\text { Environmental } \\
\text { concerns }\end{array}$ & $\begin{array}{l}\text { Deforestation from industrial } \\
\text { logging } \\
\text { Sustainability of timber } \\
\text { extraction } \\
\text { Siltation of rivers } \\
\text { Loss of biodiversity }\end{array}$ & $\begin{array}{l}\text { Industrial logging } \\
\text { Commercial hunting } \\
\text { Unsustainable local hunting } \\
\text { Diamond mining } \\
\text { Industrial waste from wood } \\
\text { treatment }\end{array}$ & $\begin{array}{l}\text { Illegal logging } \\
\text { Overfishing } \\
\text { Loss of primary forest habitat }\end{array}$ \\
\hline $\begin{array}{l}\text { Socioeconomic } \\
\text { concerns }\end{array}$ & $\begin{array}{l}\text { Few benefits reaching local } \\
\text { inhabitants } \\
\text { Underdevelopment } \\
\text { Human health and nutrition } \\
\text { High in-migration }\end{array}$ & $\begin{array}{l}\text { Poverty } \\
\text { Undernutrition } \\
\text { Underdevelopment }\end{array}$ & $\begin{array}{l}\text { Social and economic deprivation } \\
\text { Illegal land appropriation }\end{array}$ \\
\hline
\end{tabular}


moves. The Tri-National de la Sangha (TNS) is a $3.6 \times 10^{6}$ ha transboundary conservation area situated in southeast Cameroon and adjacent regions of the Republic of Congo (ROC) and the Central African Republic (CAR). It is a mosaic of three national parks areas totaling 760,000 ha (Lobéké, Cameroon; Dzangha Sangha, CAR; and Nouabalé Ndoki, ROC), various community and commercial hunting areas, and logging concessions, all interspersed with settled agricultural and agroforestry areas. The region has high biodiversity, including many threatened species. The human population is generally low and concentrated around the towns and logging camps (Table 1).

Many local, national, and international groups have an interest in both conservation and development in the region. In the Cameroon sector, natural resources are managed by l'Unité Technique Opérationnelle Sud-Est, a government agency comprising provincial and district officers of the Ministry of Environment and Forest Services working in association with local communities and conservation organizations. It is assisted by the WWF Jengi Project and the German Gesellschaft für Technische Zusammenarbeit, which are building capacity to manage the forest parks in Cameroon (WWF 2006). Dealing with such complexity requires considerable skill and a framework for coordinating policies, plans, and actions.

\section{Brazil: extractive reserves-securing the rights of local people}

The concept of the extractive reserve was proposed in 1985 by the Conselho Nacional de Seringueiros (CNS or Rubber Tappers National Council) in the Brazilian State of Acre. At the time, CNS represented rubber tappers wanting to defend their traditional lands against the advance of large-scale farming, itself supported by government policies to integrate the Amazon region into the national economy. Extractive reserves were created to ensure sustainable use and conservation of renewable natural resources while protecting the ways of life and culture of the traditional inhabitants of these lands (Allegretti 1990). Because these are legal entities under Brazilian law, they tacitly legitimize the traditional rights of communities to the land and its natural resources. Some provisions are contested, however, such as the lack of individual opportunity to own and sell land (Medina
2006).

The largest such reserve is the Reserva Extrativista Verde para Sempre, Forever Green Extractive Reserve, in Porto de Moz, created in November 2004 (Table 1). A local network of small grass-roots organizations, Comitê de Desenvolvimento Sustentável (CDS, the Committee for Sustainable Development), pressed for the establishment of the reserve to protect the landscapes and natural resources from which local people derive their livelihoods. The CDS initially helped communities tackle overfishing by outside commercial fishers, forcing the authorities to regulate fishing and ban external fishers (Moreira 2003). In the 1990s, increased land appropriation and logging by commercial timber extractors, who had been operating illegally in the area since the 1980s, sometimes with the involvement of local communities, began to threaten the forest and people's livelihoods (Salgado and Kaimowitz 2003). In an attempt to exclude loggers, the communities tried establishing communal areas comprising individually held blocks of land. The loggers ignored this extralegal arrangement, and conflict escalated (Sauer 2005). The communities and CDS then proposed creating an extractive reserve as a legal means of securing land-tenure rights compatible with people's ways of life. Loggers are now being lawfully excluded and commercial logging banned until a management plan has been formulated.

People in the reserve now face new challenges. With their land-use rights now protected, how best can they achieve sustainable economic development? Can they develop constructive alliances with outsiders to achieve this end? How can they ensure that external perspectives do not dominate local initiatives and undermine traditional practices?

\section{GUIDELINES FOR IMPLEMENTING INTEGRATED NATURAL RESOURCE MANAGEMENT AT THE LANDSCAPE LEVEL}

We propose eight guidelines for building a successful integrated natural resources management (INRM) program at the landscape level. These are drawn from lessons learned from diverse projects in the Consultative Group for International Agricultural Research (Harwood and Kassam 2003, Sayer and Campbell 2004). We explore the need for 
these guidelines by reference to the three initiatives described above.

\section{Focus on multiscale analysis and intervention}

Many technologies and projects fail because insufficient attention is paid to constraints beyond the level of the particular intervention as, for example, in many integrated conservation and development programs (McShane and Wells 2004). Landscape-level problems should be analyzed at a range of scales, upward to the higher-level social, economic, and environmental factors that set the scope for functioning at the landscape level, and downward to the workings of households, other social groups, and the biological and geophysical processes that define the landscape. Cross-scale analysis of the linkages between these levels and among the various elements within landscapes is particularly needed, concentrating on the flow of materials, energy, information, and influence, and the filters and barriers to these. Such features change over time, with new levels of organization emerging while others combine or disappear. Driving forces can shift. To track these dynamics, multiscale analysis and intervention must be ongoing and iterative.

In all three study sites, although the key stakeholders operate at a range of scales, they intersected directly or indirectly at the landscape level. In Malinau, the Center for International Forestry Research (CIFOR) and its international partners work with individual households to develop particular technologies as well as with communities, mainly to facilitate sustainable land use through processes such as community mapping and land-use planning, encouraging farmer-to-farmer visits, and providing information. At the district level, the focus is on the spatial planning abilities of district officials, whereas at a national level the attention is on forest policy issues. Most research is being conducted within a development framework, concentrating on trade-offs among the interests of different stakeholders. Although the research has encompassed different scales of functioning, this has been more through happenstance than by design, because research has been initiated at different levels somewhat independently. Formal integration of the different initiatives has been limited so far, as different groups assert their interests and independence.
In Cameroon, where forest conversion is considered the main threat to biodiversity, multiscale analysis and intervention are linked to land-use planning. Policies and practices are needed that balance different land uses and the interests of the various stakeholder groups. The transboundary dimension complicates the issue, requiring the reconciliation of different national policies. Currently, the World Wide Fund for Nature (WWF), Gesellschaft für Technische Zusammenarbeit (GTZ), and the World Conservation Union (IUCN) are facilitating work at the national level, i.e., policy development, in spatial planning and park management at the district level, and within communities seeking improvements in household livelihoods.

In Porto de Moz, the challenge is somewhat different. Although the members of the Comitê de Desenvolvimento Sustentável are well informed about their own areas, the extractive reserve is larger than their individual spheres of experience. The committee has therefore arranged visits to the whole reserve and is preparing reserve-wide information on which to base future planning, thus beginning a process of multiscale analysis. The reserve is also significant in the context of Brazil and perhaps even globally, scales at which local people's appreciation of the issues is even narrower.

\section{Develop partnerships and engage in action research}

Implementers and researchers need closer connection to the social and environmental systems that they study, learning from those who live there about what is considered important and contributing knowledge, ideas, and endeavor in ways that produce lasting improvements to people's lives. A key personal trait is empathy. Action research entwines research and development to better understand problems and find solutions specific to particular social and institutional contexts. It involves dealing with different stakeholder interests and perspectives, looking for synergies and tradeoffs, facilitating institutional change, and reflecting with partners on the progress being made (Maarleveld and Dangbegnon 1999, Hagmann et al. 2002). Such an approach also helps development more broadly by encouraging local researchers to do their own studies and to collaborate more effectively with outsiders.

In Malinau, CIFOR has forged partnerships with 
diverse groups including local communities, the district government, the government Forestry Research and Development Agency (FORDA), the state logging company Inhutani II, local NGOs and universities involved in research, and various international forestry and development organizations. Managing interactions among these requires care because of major conflicts between some of them, e.g., between the state logging company and local people, and between local people and the district government. The partnerships need constant reinforcing to build mutual trust, respect, and a sense of ownership. Action research helps. Annual meetings with all stakeholders are used to direct the research and development agenda (Wollenberg et al. 2000). Through action research, groups develop the flexibility to accommodate change and modify activities accordingly. Some interventions, such as the introduction of aquaculture, have also involved action research but without conscious social learning and adjustment.

In Cameroon, five international research and conservation organizations-CIFOR, WWF, the Wildlife Conservation Society (WCS), the World Resources Institute (WRI), and IUCN-have worked with the government to develop and implement the National Forest and Environment Sector Program. Community groups, local government, GTZ, WWF, and WCS collaborated in establishing the Tri-National de la Sangha. At a landscape scale, Unité Technique Opérationnelle (UTO) Sud-Est has introduced participatory landuse planning, including discussions on and finalization of boundaries, to improve the management of forests and wildlife. The process is reducing conflict among different user groups.

Similar collaboration among a diverse group of stakeholders is evident in Porto de Moz. The Catholic Church originally helped riparian families organize themselves to tackle common problems. When the challenges increased, largely in relation to logging, the CDS linked with social movements such as Fundação Viver Produzir e Preservar, the largest network of grass-roots organizations in the State of Pará. Later, in the struggle to create the extractive reserve, an alliance was formed with Greenpeace, an international environmental activist organization, which helped to raise awareness nationally and exert pressure on the government to establish the reserve. The partnership with the CIFOR involves identifying and developing economic opportunities for people in the reserve and how to manage the natural resources appropriately. In one community, households are engaged in action research to improve incomes from timber extraction. A local research group comprising six families that traditionally negotiated timber sales with local merchants is investigating different market options. The group meets about once a month together with representatives of the CDS to assess achievements and plan the way forward.

\section{Facilitate change rather than dictating it}

Facilitating change includes helping with negotiation, conflict management, planning, and joint decision making as well as stimulating collaborative action both between communities and others, e.g., local and national governments and development NGOs, and among households and interest groups within a landscape (Edmunds and Wollenberg 2001, Wollenberg et al. 2000).

When CIFOR initiated research in Malinau, it concentrated on finding solutions to forest-related problems. This frustrated some stakeholders who had different foci, for example, health. Most wanted less research and more action. CIFOR researchers tried to facilitate rather than dictate change, but this exposed the problem of an organization being an interested party, with its own mission and agenda, while trying to serve as an impartial facilitator. Ideally, a more neutral organization should take the lead, but other NGOs are largely absent from the area. The district government, which was only established in 2000 with an expanded mandate, currently lacks the necessary capacity.

The problem is almost the reverse in Cameroon. Until recently, the central government made most of the decisions governing land use and natural resource management. The situation is rapidly evolving, however, with WWF, IUCN, GTZ, and CIFOR, supported by the UK Department for International Development, the European Union, and the World Bank, promoting greater participation by local councils. Despite this, further progress is needed in establishing transparent and accountable management systems and more equitable benefit sharing.

In Porto de Moz, CIFOR has facilitated discussions on logging. Commercial logging is currently banned by the federal government until a management plan for the reserve has been developed, a process that 
will take time. Meanwhile, the ban is adversely affecting small-scale loggers and the communities, which traditionally negotiated sales of small amounts of timber from their areas (Medina and Shanley 2004). The CDS and CIFOR have explored the possibility of maintaining a traditional local timber market. The demand for timber by local merchants has been assessed, and communities interested in supplying this identified, but the initiative has stalled because of disagreements among some local grass-roots organizations and between the communities and the Instituto Brasileiro do Meio Ambiente e dos Recursos Naturais Renováveis, the national environment agency responsible for the reserve. Although CIFOR can help discussions in the short term, using the opportunity to learn more about the process, others eventually must play this role because carrying out local development lies outside CIFOR's brief.

\section{Promote visioning and the development of scenarios}

A key function for development agents, including researchers, is to help communities explore visions of the future under different scenarios (Franks and Blomley 2004, Wollenberg et al. 2000). Local people have to be part of this process because their insights are central to developing the logic underlying locally plausible scenarios, identifying the many uncertainties involved, and considering what is needed to achieve the desired outcomes.

In Malinau, visioning and scenario development have been used at both local and district levels, although the methods have differed (Wollenberg et al. 2000; A. Suwarno and B. M. Campbell, personal communication). Informal qualitative methods were used in villages and were adequate for that purpose. A more quantitative approach was used at the district level where a computer simulation model was built using the inputs and insights of district stakeholders. In southeast Cameroon, the WWF Jengi project has used similar techniques with local communities and technical partners to explore which land-use options provide communities with more assured access to resources and greater benefit flows. CIFOR has developed a simulation model of forest landscapes for WWF to use in this process.

Visioning and scenario development have not yet been used in Porto de Moz. Given the diversity of stakeholders and their widely differing views on how to achieve social and economic development, such a guideline would be useful. To develop a reserve management plan acceptable to all requires agreement on goals and the actions needed to attain them. Getting different stakeholders to envision a common future and how to get there is a priority.

\section{Recognize the importance of local knowledge}

The needs and perceptions of rural communities often remain hidden to outsiders unless special efforts are made to uncover them. Because people's decisions about managing natural resources are based on their knowledge and comprehension of those resources and their dynamics, understanding the nature of that knowledge is crucial to successful intervention, if only to identify what is needed to broaden the basis of decision making. Externally constructed diagnosis-and-design approaches tend to be built on distant, sometimes misplaced, views of local problems, circumstances, and possible solutions.

In Malinau, CIFOR has paid particular attention to local perspectives, both in studies of biodiversity and in activities aimed at empowering communities. Various community-centered, participatory approaches have been used to identify, discuss, score, and rank the local values of different landscapes, sites, natural resources, and species (Sheil et al. 2006). These values often differ from those held by outsiders, although many species and habitats valued by local people are also globally significant. Most value classes are utilitarian, e.g., foods, medicines, construction materials, boats, tools, and handicrafts, but some are recreational and spiritual (Sheil et al. 2006). The process not only gives local people a platform on which they can show and discuss local knowledge and practices, but it enhances conservation planning. New species were discovered, and areas of particular conservation value highlighted. By articulating their values, people can reflect on what they need to conserve. Similarities and differences in the values held by different stakeholder groups can form a basis for dialogue about what should be conserved, why, how, and by whom. A local constituency for conservation can develop. For example, the Setulang community in Malinau, with CIFOR's assistance, won a national environmental prize for choosing to conserve their forest rather than have it commercially logged, thereby foregoing the 
opportunity to be paid substantial royalties (Iwan 2003, CIFOR 2004). They met the Indonesian president, which raised their status at the district level and encouraged them to speak with greater confidence about their natural resource management activities.

Multidisciplinary landscape assessment is also being done in Cameroon. Until the mid-1990s, the government paid little attention to the local practices and rights of indigenous people, but lately the concept of community involvement has become more widely accepted. Local Bantu and Baka pygmy populations were consulted when the three national parks in southeast Cameroon were established. Access by the Baka to some areas within these parks, including spiritual sites, was negotiated (Usongo and Tchikangwa 2004). The Baka can now legally harvest bush mango, wild yams, honey, and fish from parts of Lobéké National Park. Fourteen community hunting areas, managed by local people and leased seasonally to safari operators for trophy hunting, have been established in forests bordering the national parks. Nevertheless, despite these advances, the legal basis for the rights of indigenous people is still weak. The laws are complex and only poorly reflect this particular sociocultural context. Local people must be empowered to contribute to debates on law reform and implementation, including the extent to which customary rules can be made statutory. Uncovering the breadth and depth of people's local knowledge and practice is integral to this process.

In Porto de Moz, one community received a substantial grant in 2001 to implement a program of sustainable extraction and processing of timber. Little progress was made, however, mainly because the legal and technical criteria for such management were completely foreign to local traditions. This again highlights the need to document local practices and integrate the information into the official community forestry management plans. This is now underway.

\section{Foster social learning and adaptive management}

People act in their own best interests but with limitations. Some of these are because of partial understanding and perceptions of the options; others are imposed by social conventions and outside constraints. People need opportunities to broaden their knowledge, understanding, and range of options; to find out what works and what does not; and to adapt accordingly. This is best done in a social learning environment, preferably with the involvement of many different stakeholders, so that their individual knowledge, skills, and energy can be combined to address common problems (Maarleveld and Dangbegnon 1999). A prerequisite for this is some balance of power or influence among the stakeholders to allow for more effective dialogue among different interest groups. One indication that social learning and adaptive management are being taken seriously is monitoring and evaluation by the community of their actions.

Despite its common-sense appeal, this guideline is only slowly being adopted. In Malinau, adaptive management has not been accepted by all stakeholders. The state logging company has a rigid 20-yr plan for working its concessions. Consequently, efforts to establish reduced-impact logging have largely failed. The small-scale operators have no long-term perspective; they function opportunistically. Local people are highly adaptive in their use of land and its resources, but this adaptability is not the product of a purposeful process.

The community-based action research project has consciously tried to foster social learning and adaptive management. At regular meetings, researchers and community members discuss and seek consensus on the nature of particular problems. They plan actions, assess progress, extract lessons, and arrange future research and development activities. A similar approach has been tried at the district level, so far with little success. With so many nonintegrated projects, getting people together to reflect on progress is difficult. District officials are supposed to monitor and evaluate the progress of development activities, particularly on achieving broader landscape and livelihood goals, but this has not really happened. Limited capacity is one probable reason. Key officials claim to be busy with other administrative tasks. Monitoring and evaluation have costs.

The guideline seems particularly relevant in Cameroon, where there are more than 250 ethnic groups, many with overlapping distributions. Local organization is weak, and traditional structures and customs are being eroded. People need to be brought together to identify common problems and work jointly to resolve them. In the Tri-National de la 
Sangha (TNS), WWF and GTZ are working with local communities to build capacity in social organization and technical skills for the design and management of micro-projects based on forest products. CIFOR and WWF, working with local partners, have set up an action research program that includes ongoing monitoring, largely in relation to biodiversity conservation, which is fed back into annual work plans. Elsewhere, CIFOR has been working with government officials and NGOs more generally to create an enabling environment for such projects. Joint action, social learning, and adaptation are central to all these initiatives.

The organizational and institutional landscape in Porto de Moz is similarly complex, involving many different agencies and individuals, all of which have their own, sometimes conflicting, interests, expectations, and visions. Who then has the legitimacy to make crucial decisions? Currently, the Brazilian government's perspectives dominate, sometimes to the detriment of local people. Even the support agencies and some NGOs tend to follow the government line. Local perspectives need exposure and legitimacy so that they are taken into account when policies are formed and implemented. The issues can be debated and common positions reached in multistakeholder forums, but to be effective the power relationships and communication between stakeholders need to be more equitable. Until this happens, the opportunities for joint action, social learning, and conscious adaptation are limited.

\section{Concentrate on both people and their natural resources, including biodiversity}

Natural resources are important not only for their intrinsic worth and value as safety nets during times of stress, but also because they are the foundation for economic growth and social development. The balance between conservation and development necessarily involves trade-offs, although the eventual outcome is usually more viable than a partisan approach (Lee et al. 2001, Tomich et al. 2001). Conservation in the face of ongoing poverty and deprivation is unrealistic; development that destroys the natural resource base and environmental service functions is unsound.

The Malinau project has focused on both people and biodiversity, although usually in separate projects. The researchers differ on the relative importance of these two foci, particularly in relation to CIFOR's mandate. As a result, district officials have sometimes received divergent views on certain issues, e.g., oil palm expansion, which diminishes biodiversity but has a positive development outcome for some stakeholders if governance is strong. Local people want to receive benefits from extracted forest resources, but they also often wish to protect the resources. The district government expresses its support for conservation but works hand-in-hand with small-scale operators in highly destructive logging operations. The large-scale timber concessionaires use reasonable practices, but few people living in the concession areas benefit. National-level authorities are required to devolve responsibility but work to retain some control. How should such trade-offs be handled?

Local people cannot be expected to forego income from timber simply for the sake of preserving the global existence or option values of biodiversity. One possibility is for those wanting to conserve biodiversity to pay those making land-use decisions to conserve, not destroy, it. This was explored in the case of the Setulang community, which wanted to conserve an area of forest but was under pressure to sell the logging rights to a timber company. Finding a buyer for the biodiversity in the forest was not easy for a number of reasons. One is the lower transaction costs of conservation associated with official protected areas (S. Wunder, personal communication).

Similar tensions between protection and use exist at the other sites. In southeast Cameroon, the seminomadic Baka depend on forests for their livelihoods. At least $90 \%$ of the foods gathered by Baka pygmies living next to Lobéké National Park come from within the park. Conserving the biodiversity of the region depends on recognizing this dependence and working with people to find acceptable trade-offs in the limits to protection and use. In Porto de Moz, although the creation of an extractive reserve solved the problem of expropriation of resources by outsiders, it also caused new ones. Historically, people in Porto de Moz used the forest resources without the control or support of the Brazilian government. Now they have to obey externally designed and imposed regulations. Previously, they defended their resources against outsiders, developed local management rules, and were free to use or abuse the resources as they saw fit, although, in general, households understood the importance of resource 
conservation. Nevertheless, times change, and pressures are increasing. The statutes governing the extractive reserve now limit some uses, in extent if not in kind. If management plans and rules are to be widely accepted, local people's dependence on resources from the reserve must be considered.

\section{Embrace complexity}

The livelihoods of rural people comprise an everchanging portfolio of activities: some are regular, seasonal occurrences; some take advantage of windfall opportunities; some are forced on people having to cope with sudden external pressures. Land users not only aim to maximize production but do other things as well. Production is optimized within the constraints of the time and resources needed to satisfy other goals. Landscapes are also varied, with biophysical, social, and cultural elements shaping land-use patterns and land-management decisions. The result is a kaleidoscope of actions and responses that contribute much to the resilience of these socialecological systems. Given this complexity, there are many pitfalls for implementers. Not to confront complexity inevitably leads to partial and unsuccessful solutions; becoming enmeshed in detail can obscure the real problems (Sayer and Campbell 2004). The appropriate balance in each instance may be unique.

The landscapes at all three sites show considerable complexity, although this was dealt with differently and to varying extents in each case. In Malinau, the different research groups viewed land use from a range of perspectives and engaged the various stakeholders accordingly. Developing a simulation model brought out the complexity, although integration has yet to be achieved because there is no agreed vision for the district.

In Cameroon, the issue of complexity revolves around people, policies, and practices. Considerable attention is focused on drawing up and implementing the transboundary agreement governing the TNS, and on establishing appropriate policies and institutions to support this large and complex project. The laws that regulate benefit sharing, stakeholders ownership, and comanagement practices do not adequately address the plight of local communities or help integrate them (Usongo and Tchikangwa 2004). Although well meaning, the laws are only intermittently applied and tend to favor influential stakeholders such as logging concerns, safari companies, and local politicians. Confusion over ownership and responsibilities has produced needless conflicts between local communities, which are the traditional custodians, and government authorities and the private sector. The establishment of UTO Sud-Est has helped integrate the interests and efforts of different stakeholders and synergize and harmonize the efforts of technical partners, but the complexity of other elements in the landscape still needs to be confronted. The simulation model developed by CIFOR for WWF is helping to pinpoint the priority areas.

In some cases, addressing complexity is constrained by a lack of resources, so that strategic choices have to be made about what should be tackled first. In Porto de Moz, the CDS focused on the complexity of reserve management, including building strategic alliances with external organizations able to provide appropriate information and insights. For CIFOR, this means identifying the possibilities and limitations of different forest management options and helping to correct some external misconceptions about the potential of different land uses in tropical forests. CIFOR researchers are also documenting and evaluating the traditional attitudes of communities to conservation, their current resource-use practices, and the prospects for building on these. The complexity inherent in these issues is gradually being unraveled, but in a structured and useful way.

\section{CONCLUSIONS}

Most guidelines are being practiced to varying extents at all three sites, but nowhere are all being applied in concert. They have been discovered and used largely through trial and error rather than by design. Taken together, they form a mutually reinforcing framework of actions in support of integrated natural resources management (INRM). Nevertheless, it is neither necessary nor realistic for all of them to be implemented concurrently, although some sequencing is useful. The order given above is broadly the progression that we think will work best. The process is iterative, with the actions indicated in the guidelines being repeatable at intervals to extend and strengthen earlier efforts.

We obviously believe that all eight guidelines are necessary for effective INRM, but are they sufficient? This is more difficult to assess at this 
stage, given the emerging nature of INRM. We need more information on how to implement the guidelines and the constraints on this. Application will likely vary from place to place, so we need to know the contextual features that dictate one approach over another in a given circumstance. The three studies illustrate this well. The initial emphasis on forestry and biodiversity in Malinau contrasts strongly with the focus on human livelihoods in Porto de Moz or the tension between protection and human use of forest resources in the Tri-National de la Sangha. All three initiatives evolved rapidly from their diverse beginnings to converge on a broadly similar set of issues and approaches: organizational and institutional development, including capacity building; empowerment of local people; negotiation; conflict resolution and tradeoffs; and sustainable use of resources.

Many of the guidelines involve empowering local stakeholders directly, by allowing them to be heard and through amplifying their voices, and indirectly, by building their capacity to be more effective implementers of their own development and conservation efforts. It is critical that it is the people's voices that are heard, not those of outsiders conveyed by unwitting proxies. There is often a tension between outsiders, who generally see a bigger and sometimes more complete picture, and local people whose perspectives and interests are often narrower and more self-centered, but this is no reason for assuming that the broader view should automatically prevail. Where there are many outside agencies, each with its own mission and agenda, the tendency to co-opt local people in pursuit of externally conceived goals is common. Instead, convergence is needed, which is what the guidelines on action research, facilitation, visioning, scenario development, and giving due weight to local knowledge are all designed to do. Crucial to all these, however, is the need for more equitable sharing of power and responsibility. This could be a guideline on its own, but we prefer to see it as a cross-cutting principle.

Reviewing the context studies in the light of these guidelines suggests some lessons:

- In dealing with complex and dynamic systems, begin with an open exploratory phase to get a feel for the structure and scale of the issues.

- Initial work should focus on learning and listening. Formal characterization, mapping, and planning such as diagnosis-and-design can limit the scope.

- The main outcomes of applying the guidelines should be more empowered stakeholders, especially local people; reduced uncertainties; more informed choices; and greater capacity to direct and adapt to change.

- More attention should be paid to learning within project teams and to applying the lessons to management.

- Action research, conducted with joint learning and adaptive management, enables problems to be solved incrementally, which is important when knowledge of a problem is incomplete.

- Although having substantial financial and human resources helps, the guidelines can still be applied in constrained circumstances, e.g., Porto de Moz. Not all elements need be implemented immediately or fully, but their essence can serve as a guide. As such, the guidelines are independent of scale.

- Differing agendas of stakeholders, narrow project objectives, and short time frames make it difficult to implement the guidelines, but the problems can be overcome by progressive iteration of the guidelines, amplifying their extent as conditions allow.

- The last guideline, i.e., embrace complexity, is both a credo and a coda. It reflects the reality that complex problems must be confronted, but it is also the thread that runs through the other guidelines, binding them together.

Responses to this article can be read online at:

http://www.ecologyandsociety.org/voll1/iss2/art30/responses/

\section{Acknowledgments:}

For funding the work in Malinau we thank the International Tropical Timber Organization (ITTO). Numerous colleagues, too many to mention, 
have contributed to the work in Malinau. We thank Jeff Sayer for stimulating many of our thoughts on this topic, and in particular for facilitating engagement in Cameroon. We are also grateful to two anonymous referees for useful comments.

\section{LITERATURE CITED}

Allegretti, M. 1990. Extractive reserves: an alternative for reconciling development and environmental conservation in Amazonia. Pages 252-264 in A. B. Anderson, editor. Alternatives to deforestation: steps toward sustainable use of the Amazon rain forest. Columbia University Press, New York, New York, USA.

Campbell, B. M., P. Gunarso, K. Kartawinata, P. Levang, S. Rhee, D. Sheil, P. Sist, and E. Wollenberg. 2003. Empowering forest dwellers and managing forests more sustainably in the landscapes of Borneo. Pages 79-96 in R. R. Harwood and A. H. Kassam, editors. Examples of research problems, approaches and partnerships in action in the CGIAR: research towards integrated natural resources management. Interim Science Council, Consultative Group on International Agricultural Research, FAO, Rome, Italy.

Center for International Forestry Research (CIFOR). 2004. CIFOR helps village win major environmental award. Available online at: http://w ww.cifor.cgiar.org/Publications/Corporate/NewsOnline/ NewsOnline33/environmental.htm.

Colchester, M. 1994. Slave and enclave: the political ecology of equatorial Africa. World Rainforest Movement, Penang, Malaysia.

Davenport, T., and L. Usongo. 1997. Justification and recommendations for the gazettement of a "protected area" in Lobeke Forest South East Cameroon. Report prepared for the Ministry of Environment and Forests, Cameroon. Lobeke Project, World Wildlife Fund, Gland, Switzerland, and Global Environment Facility, World Bank, Washington, D.C., USA.

Edmunds, D., and E. Wollenberg. 2001. A strategic approach to multistakeholder negotiations. Development and Change 32:231-253.
Engel, S., and C. Palmer. 2006. Who owns the right? The determinants of community benefits from logging in Indonesia. Forest Policy and Economics 8:434-446.

Franks, P., and T. Blomley. 2004. Fitting ICD into a project framework: the CARE experience. Pages 77-97 in T. O. McShane and M. P. Wells, editors. Getting biodiversity projects to work: towards more effective conservation and development. Columbia University Press, New York, New York, USA.

Hagmann, J., E. Chuma, K. Murwira, M. Connolly, and P. Ficarelli. 2002. Success factors in integrated natural resource management R\&D: lessons from practice. Conservation Ecology 5 (2):29. [online] URL:http://www.consecol.org/vol5/ iss $2 / \operatorname{art} 29 /$.

Harwood, R. R., and A. H. Kassam, editors. 2003. Examples of research problems, approaches and partnerships in action in the CGIAR: research towards integrated natural resources management. Interim Science Council, Consultative Group on International Agricultural Research, FAO, Rome, Italy.

Iwan, R. 2003. Setulang village protects its river! Policy Matters 12:152-153. Available online at: $\underline{\mathrm{htt}}$ p://www.iucn.org/themes/ceesp/Publications/newsletter/ PM12 - Section III.2.pdf.

Lee, D. R., P. J. Ferraro, and C. B. Barrett. 2001. Introduction: changing perspectives on agricultural intensification, economic development and the environment. Pages 1-16 in D. R. Lee and C. B. Barrett, editors. Tradeoffs or synergies? Agricultural intensification, economic development and the environment. CABI, Wallingford, U. K.

Maarleveld, M., and C. Dangbegnon. 1999. Managing natural resources: a social learning perspective. Agriculture and Human Values 16:267-280.

Medina, G. 2006. Castanheiros $\mathrm{x}$ grileiros: conflitos na última fronteira florestal do Pará. Ciência Hoje 223(4):60-63.

Medina, G., and P. Shanley. 2004. Big trees, small favors: loggers and communities in Amazónia. Bois \& Forêts des Tropiques 282(4):19-25.

McShane, T., and M. P. Wells, editors. 2004. 
Getting biodiversity projects to work: towards more effective conservation and development. Columbia University Press, New York, New York, USA.

Moreira, E. 2003. Tradição em tempos de modernidade: reprodução social numa comunidade varzeira do rio Xingu-Pa. Editora Universitária Pioneira na Amazónia, Belém, Brazil.

Salgado, I., and D. Kaimowitz. 2003. Porto de Moz: o prefeito, "dono do município." Pages 219-252 in F. Toni and D. Kaimowitz, editors. Municípios e gestão florestal na Amazónia. A. S. Editores, Natal, Brazil.

Sauer, S., editor. 2005. Human rights violations in the Amazon: conflict and violence in the State of Pará. Comisão Pastoral da Terra (CPT), Goiânia; Justiça Global, Rio de Janeiro; Terra de Direitos, Curitiba, Brazil. [online] URL: http://www.global.o rg.br/docs/relatorioparaingles.pdf.

Sayer, J., and B. Campbell. 2004. The science of sustainable development: local livelihoods and the global environment. Cambridge University Press, Cambridge, U. K.

Sheil, D., R. Puri, M. Wan, I. Basuki, M. van Heist, N. Liswanti, Rukmiyati, I. Rachmatika, and I. Samsoedin. 2006. Local people's priorities for biodiversity: examples from the forests of Indonesian Borneo. Ambio15:17-24.

Tomich, T. P., M. van Noordwijk, S. Budidarsono, A. Gillison, T. Kusumanto, D. Murdiyarso, F. Stolle, and A. M. Fagi. 2001. Agricultural intensification, deforestation and the environment: assessing the tradeoffs in Sumatra, Indonesia. Pages 221-244 in D. R. Lee and C. B. Barrett, editors. Tradeoffs or synergies? Agricultural intensification, economic development and the environment. CABI, Wallingford, UK.

Usongo, L., and B. Tchikangwa. 2004. Participatory approaches towards forest conservation: the case of Lobeke National Park, Southeast Cameroon. International Journal of Sustainable Development and World Ecology2:119-127.

Wilkie, D. S., N. Gami, B. Difara, C. Angoue, A. Mieuguem, and A. T. Kamdem. 2001. Sociocultural reconnaissance: ecoregion action program (ERAP), Central Africa. World Wildlife Fund Technical Report, Gland, Switzerland.
Wollenberg, E., D. Edmunds, and L. Buck. 2000. Using scenarios to make decisions about the future: anticipatory learning for the adaptive comanagement of community forests. Landscape and Urban Planning 47:65-77.

World Wildlife Fund (WWF). 2006. Central Africa Programme: Jengi Project, Cameroon. Available online at: http://www.panda.org/about wwf/ where we work/africa/where/cameroon/jengi project/ index.cfm. 